\title{
Does a property rights regime affect the outcome of European inland commercial fisheries?
}

\author{
M. Sipponen ${ }^{(1)}$, M. Mitchell(1) ${ }^{(1)}$ J. Vanberg ${ }^{(1)}$ \\ Received May 7, 2010 / Reçu le 7 mai 2010 \\ Revised September 15, 2010 / Révisé le 15 septembre 2010 \\ Accepted September 15, 2010 / Accepté le 15 septembre 2010
}

\begin{abstract}
Key-words: $\quad$ European inland commercial fisheries exhibit a wide spectrum of fishing inland fisheries, property rights, institutions, Europe modes, and have experienced major changes over recent decades. A peculiar feature of inland fisheries is the deep dependence on resources usually owned by someone else than a fisher. Therefore institutions such as property rights regimes, have a profound influence on the prerequisites to carry out commercial inland fisheries. We examined whether two main property right regimes, public or private, have alleviated commercial inland fishers' access to fishing grounds in member countries of the European Inland Fisheries Advisory Commission, EIFAC. Public ownership prevailed in two countries out of three. Commercial inland catch and employment (number of fishers) for countries with mostly public ownership were nearly six times greater than for those with mostly private ownership. Ratios of both commercial inland catch and employment to inland water area were over nine times greater for countries were fisheries were publicly managed in comparison with privately managed fisheries. This outcome contradicts the presumption of privatisation of fishing rights as a tool to increase efficiency of commercial utilisation of inland water fish resources.
\end{abstract}

\section{ABSTRACT}

\section{RÉSUMÉ}

Le régime des droits de propriété affecte-t-il les résultats des pêcheries commerciales des eaux continentales européennes?

Mots-clés : pêcheries continentales, droits de propriété, institutions, Europe
Les pêcheries commerciales dans les eaux continentales européennes présentent une large gamme de modes de pêche et ont subi des changements importants ces dernières décades. Une caractéristique particulière des pêcheries intérieures est la forte dépendance des ressources souvent possédées par d'autres que les pêcheurs. Par conséquent, les institutions comme les régimes de droit à la propriété ont une forte influence sur les conditions préalables à la mise en place des pêcheries commerciales intérieures. Nous avons examiné comment les deux régimes principaux de droit à la propriété, public ou privé, influent sur l'accès des pêcheurs commerciaux aux sites de pêche dans les pays membres de la Commission Européenne Consultative pour la Pêche dans les Eaux Intérieures, CECPI. La propriété publique prévaut dans deux pays sur trois. Les captures commerciales et le nombre d'emplois dans les pays de propriété publique principale sont près de six fois plus forts que dans les pays à propriété privée majoritaire. Les rapports à la fois entre captures commerciales, emploi et la surface des eaux pêchées sont plus de neuf fois supérieurs pour les pays où les pêcheries sont gérées publiquement.

(1) Centre for Economic Development, Transport and the Environment for Central Finland, P.O. Box 250, 40101 Jyväskylä, Finland, matti.sipponen@ely-keskus.fi 
Ces résultats contredisent la supposition que la privatisation des droits de pêche serait un moyen d'accroître l'efficacité d'utilisation des ressources piscicoles des eaux intérieures.

\section{INTRODUCTION}

Commercial inland fisheries like any other economic activity are interlinked with their operational environment. European inland commercial fisheries exhibit a wide spectrum of fishing modes, targeting species ranging from migratory salmon and eel to lacustrine whitefish, pike-perch, perch and cyprinids using gears such as gill nets, traps and trawls. They have experienced major changes over recent decades, especially structural changes. As a branch of economic activity, commercial inland fisheries are more closely bound up with their operational environment than other types of enterprises, dependent, as they are, on factors outside of their own decision-making powers (Sipponen et al., 1999). A peculiar feature of inland fisheries is the deep dependence on resources usually owned by someone else than a fisher. Therefore institutions such as property rights regimes, have a profound influence on the prerequisites to carry out commercial inland fisheries.

According to premises of market economy, decisions of independent economic actors aiming to maximize their benefits will lead to both private and social optimum. Consequently the free market, combined with adequately defined property rights, should allocate the use of fishery resources in the most efficient way. During the past decennies privatisation of fishing rights were seen as a tool to improve the efficiency of commercial fishing (see e.g. Symes, 1998a), but recent experience favour solutions based on co-management of fishery resources (Ostrom et al., 1999; Ostrom, 2000), where managerial responsibilities are shared between government and local players.

Property rights in European inland fisheries have been studied by O'Kelly (1976). Later European inland fisheries have been widely described by Dill $(1990,1993)$. In these latter reports commercial fisheries were seen as a declining industry. Review of Inland Fisheries and Aquaculture in the EIFAC (European Inland Fisheries Advisory Commission) area by Subregion and Subsector (FAO, 1995) described the performance of commercial inland fisheries in northern, eastern, southern and western subregions, respectively. These are among the few easily accessible compilations related with the topic in question.

Increased socio-economic significance of recreational fisheries has overshadowed the importance of commercial inland fisheries in recent years (Aps et al., 2004). One indication of this is the paucity of research addressing directly on socio-economic aspects of commercial inland fisheries. While some of the recent trends facilitate commercial fishing (such as increasing market demand for white-fleshed freshwater fish, appreciation of the cultural values inherent in commercial fisheries and increased financing opportunities in EU member countries), other factors hinder its development (environmental degradation, low water quality, stock depletion).

The reliance of inland fisheries on ecosystems as a basis of production creates the need to identify different resource systems. There are fundamental differences between fisheries in lakes and reservoirs compared to those in rivers. Lake fisheries are more or less closed systems with confined fish stocks as opposed to river fisheries, which form open systems. Reservoirs cover a range of possibilities intermediate between rivers and lakes (FAO, 1997). When migrating species are harvested, ecological boundaries and the range of interests in management enlarge to cover also remote grazing areas of these species. Harvesting of migrating species is usually regulated by international treaties and managerial decisions need international co-operation. 


\section{DATA AND METHODS}

The focus of this study is on commercial capture fisheries mainly in lakes and rivers, with the purpose of having a clear distinction from both recreational fisheries and aquaculture carried out in estuaries. We examined whether two main property right regimes prevailing in fisheries in European inland waters, public or private, have alleviated commercial inland fishers' access to fishing grounds. Also the performance of commercial inland fisheries under these regimes was assessed quantitatively by using such socio-economic indicators as employment and catch. These provided most comprehensive data, although other socioeconomic indicators can be identified also.

Even in Europe it was quite difficult to find reliable statistics about inland capture fisheries carried out on lakes and rivers and their socio-economic significance. In their report on employment on fisheries sector, Salz et al. (2006) stated that most EU member states could indicate the number of persons involved in commercial inland (freshwater) fishing, usually on the basis of the register of permits. The numbers of inland fishermen were small and little or no research had been carried out in this area. According to the European Commission (2007), great care has to be taken in analysing employment data because there is a lack of harmonisation in the definitions and concepts used in the collection and compilation of the data by the national authorities.

In this study we use concept public ownership synonymous with state ownership, as the data did not make clear distinction between these terms, but instead they were used interchangeably. Access of commercial fishers to fishing grounds in inland waters is subject to national legislation and is a question of national decision-making.

Basic data on property rights regimes and access of commercial fishers to fishing grounds were gathered through questionnaires directed to EIFAC national correspondents (including a feedback questionnaire of draft text version aiming to verify the details) and extensive searches via internet and literature (i.e. government and FAO websites and scientific articles). These data were also used to compile socio-economic and other indicators for individual country profiles (for more details see Mitchell et al., 2010), which were mainly quantified for the years 2005 and 2006. Socio-economic indicators were here classified on the basis of the property rights regime. Due to enlargement of the European Union to 27 member states, 25 of the 33 EIFAC member countries have EU membership.

\section{DEFINITIONS FOR INLAND FISHERIES AND ITS GEOGRAPHICAL DISTRIBUTION}

According to FAO (1992), inland fisheries were "fisheries which are carried out in freshwater or estuaries and whose target species are those that spend all or part of their life-cycle therein". Five years later inland fisheries were defined by FAO (1997) as "any activity conducted to extract fish or other aquatic organisms from inland waters". Existing definitions according to FAO (1999) separate different fisheries based on fishing methods (activity-based), specific biological resources utilised (species-based), biogeographical limits (type-based) or according to aspects related to socio-economics (employment or income levels).

In many EIFAC member countries national legislation and by-laws define different types of fishing (e.g. in order to allocate fishing rights or to determine individual fisher's eligibility for financial subsidies). These definitions can be used as tools to implement fisheries policies. In practice the issue of a clear definition for commercial inland fishing will partly be resolved on the national level during the course of implementation of the European Fisheries Fund (EEF), because the eligibility of fishers needs to be checked when handing out subsidies.

The EFF recognizes 'inland fishing' as catch activities "carried out for commercial purposes by vessels operating exclusively in inland waters" (European Commission, 2008). In commercial inland fisheries, the fish resource that is extracted or caught will be marketed and sold, thus creating economic output in the process. Inland and commercial fishing, respectively, have 
many definitions hampering effort to categorize them, and some countries lack legal definition for inland fisheries (see also Leria, 2001).

Many fisheries and fishing communities, which vary in size, have developed in regions and sites where biological resources have facilitated economically successful harvesting. Most important geographical areas for inland commercial fisheries are usually well defined in EIFAC member countries (Mitchell et al., 2010). Of the different types of water bodies, lakes, rivers, estuaries, lagoons, deltas, ponds and reservoirs are all under commercial utilisation, but we focus here on lake fisheries.

It would also be important to notice the difference between the concepts of fishing and fisheries, especially when examining employment. According to our understanding, fishing refers to the activity itself, while fisheries refer to all aspects of the industry, including trade, processing, management, research and administration. This difference does not always seem to be recognised leading to confusion.

\section{INSTITUTIONAL ENVIRONMENT}

The political-administrative environment consists of the legislative and administrative institutions and decision-making relating to the use of fishery resources. North (1990) defines institutions as humanly devised constraints that shape human interaction. Institutions may also be defined as social decision systems that lay down rules for adjusting and accommodating, over time, conflicting demands from different interest groups in a society (Ciriacy-Wantrup and Bishop, 1975). Such institutions include laws, constitutions, traditions, and moral and ethical structures. In itself the market also is an institution. Institutions direct, control, restrain, or at least influence almost every activity and interpersonal relationship in a modern society. According to this broad definition, in respect to fisheries, institutions include the processes and organisations that develop and implement the rules affecting the use of fishery resources (OECD, 1997). In particular, legislation and property rights are essential institutions in many inland fisheries, as they determine management responsibilities and access rules.

In EIFAC member countries inland fisheries are managed, typically at a state level, by different ministries, boards and departments. Administrative structures and management procedures have developed in each country on the basis of national priorities and acknowledged importance of inland fisheries. In many countries where inland fisheries have a stake, there exists regional or local management bodies (Mitchell et al., 2010). The administrative structure provides prerequisites for maintaining and enhancing institutional sustainability of the fisheries system. Furthermore, the mere existence of a state fisheries administration, in addition to other hierarchies established for fisheries management, indicates the social significance of fisheries and the development potential it is thought to have.

The basic enactment of existing fisheries legislation in EIFAC member countries often originates from the 1980s and 1990s (Mitchell et al., 2010). Fisheries are regulated by different types of primary and secondary legislation (laws, acts, decrees and regulations). Common priorities in national fisheries policies are protection of physical environment, enhancement of exploited fish stocks and maintenance of socio-economic viability of fisheries-dependent communities.

\section{PROPERTY RIGHTS}

\section{> REGIMES AND TYPES OF PROPERTY RIGHTS}

Property rights can be classified by regime (open access, state property, communal property and private property) or by type (access, withdrawal/harvesting, management, exclusion and alienation rights). Those having rights to go to fish hold use rights. The two levels of use rights are access rights and withdrawal or harvest rights. The former authorise entry into fishery, 
or a specific fishing ground, the latter involve the right to engage in a specific level of fishing effort or to take a specific catch (see e.g. Charles, 2001).

Some confusion regarding property systems of fisheries rights may arise because the terms property and rights are often used interchangeably. The term property is often confused with a tangible thing that is owned. However, property is not an object but a concentration of power over things and resources. Also Bromley (1991) states that the term "property" refers not to an object or a natural resource but rather to the benefit stream that arises from that object or resource. Thus, the key attribute of property is not the resource itself but the social relation it involves: the right to benefit from the resource flow while excluding others. In other words property is a system of authority established by government. It is a set of rights to the control of assets. The term "property right" is widely used in fisheries and is an enforceable authority to undertake particular actions in specific domain (see Ostrom, 2000).

Symes (1998b) points out that fisheries property rights often refer to use (or usufruct, i.e. the right to use and derive profit from a piece of property belonging to another, provided the property itself remain undiminished and uninjured in any way) rather than real property rights. True property rights within fisheries are rare, while use rights are defined as access rights or harvest rights.

Usually a fishing licence granted by state, regional, municipal or local management body or by private owner entitles right to access and harvest. There exists a variety of possible use rights (access, harvest) arrangements as regards European commercial inland fisheries.

A particular resource, and fish are a good example, may be held under more than one property rights regime, or resource management regime. A resource management regime is a structure of rights and duties characterizing the relationship of individuals to one another with respect to that particular resource. In an economy that is otherwise conducive to efficiency, nonattenuated property rights are assumed to ensure efficient allocations in a well-functioning market.

Berkes and Farvar (1989) and Berkes et al. (1989) describe idealized types of property rights (or use rights according to Symes (1998b)) regimes:

- Open access (or the absence of well-defined property rights) (res nullius): access is free and open to all. However, even private property rights regime may turn to resemble that of an open access, if any kind of a formal body responsible for management has not been established, and consequently there does not exist management rules and surveillance.

- State property (res publica): the state holds the rights to the resource in trust, on behalf of its citizens.

- Communal property (res communes): held by an identifiable community of users with rights to exclude others from using the resource. This regime represents private property for the group of co-owners, since all others are excluded from use and decision making (Bromley, 1991).

- Private property (res privatae): an individual or corporation has the right to exclude others from using the resource and to regulate its use. Private property regimes in fisheries can be exemplified by the Individual Transferable Quota (ITQ) system. Under this system, a proportion of the TAC (Total Allowable Catch) is assigned to an individual or a group. The individual does not have a property in the resource, but has an exclusive right to harvest. The subject of economic transactions is not a tangible object but a right of usufruct.

Fish as migratory and fugitive resources share two key characteristics of common property resources: the exclusion of potential users is problematic, and subtractability, which means that each user is capable of subtracting from the welfare of others (Berkes et al., 1989). However, a fish can not casually be labelled as a common property resource, but depending upon where it is found, how it is caught and by whom, it can be res nullius, res publica, res communes, or private property.

In this study we have used a dicotomous distribution of property rights regimes into two basic types: public/state property and private property, respectively. 
Table I

General ownership of inland waters/fisheries for EIFAC member countries.

Tableau I

Données d'ensemble sur la propriété des eaux intérieures vis-à-vis de la pêche dans les pays membres de la CECPI.

\begin{tabular}{|l|c|c|c|}
\hline $\begin{array}{l}\text { Type of inland } \\
\text { water/fishery }\end{array}$ & $\begin{array}{c}\text { Number of countries with } \\
\text { mostly state/public ownership }\end{array}$ & $\begin{array}{c}\text { Number of countries with } \\
\text { mostly private ownership }\end{array}$ & $\begin{array}{c}\text { Total number of } \\
\text { countries included }\end{array}$ \\
\hline Lakes & $18(62 \%)$ & $11(38 \%)$ & $29(100 \%)$ \\
\hline Rivers & $21(64 \%)$ & $12(36 \%)$ & $33(100 \%)$ \\
\hline Reservoirs & $19(70 \%)$ & $8(30 \%)$ & $27(100 \%)$ \\
\hline Estuaries/lagoons & $16(84 \%)$ & $3(16 \%)$ & $19(100 \%)$ \\
\hline
\end{tabular}

\section{> PROPERTY RIGHT REGIMES OF INLAND WATERS AND FISHERIES}

This study showed that in EIFAC member countries state or public ownership of inland waters and fisheries dominates, while fewer countries adhere mostly private ownership (Table I). Public ownership prevails in two countries out of three; the percentage share varies slightly based on the type of water body or fishery. According to the classical and to some degree stereotyped description, inland water areas in Scandinavia and Great Britain (excluding estuaries) are in private possession, whereas in the rest of Europe they are often state/public property. Country profiles (Mitchell et al., 2010) confirm this general rule (Table II), although some countries are more complex (e.g. Ireland).

We also found that there is limited information on the accessibility of inland waters for commercial fishing in EIFAC member countries. In Estonia, the availability of inland waters to commercial fisheries is approximately $90 \%$ of the total surface area of lakes and reservoirs and $10 \%$ of the total length of rivers. Commercial inland fisheries in Finland concentrate on 67 single lakes covering $14633 \mathrm{~km}^{2}$ (44\% of all inland waters), which are waters that fishers regard as their main grounds. In Germany, approximately $30 \%$ of the total surface area of inland waters is accessible for commercial fishers, whereas together about $47 \%$ is used for inland fisheries (including angling and aquaculture). However, these percentages differ in each federal state. In Poland, the accessibility of inland water areas to commercial fishing is as follows: $2700 \mathrm{~km}^{2}$ of lakes (87\%), $220 \mathrm{~km}^{2}$ of reservoirs (40\%) and $785 \mathrm{~km}^{2}$ of estuaries (100\%). In Sweden, licenced professional fishermen can be found in the five largest lakes, Vänern, Vättern, Mälaren, Hjälmaren and Storjön. Additionally, professional fishing occurs in 21 lakes in southern and central Sweden and in 13 lakes/reservoirs in Northern Sweden.

\section{SOCIO-ECONOMIC INDICATORS: CATCH AND EMPLOYMENT}

The most common indicators illustrating the socio-economic significance of commercial inland fisheries are commercial inland catch, its value and the number of fishers, i.e. employment as fishers.

In certain countries the economic value of commercial inland catch exceeds largely its proportion in weight compared to commercial marine catches. For example, proportions of inland catch to total catch (inland plus marine) in terms of weight and value, respectively, are $5 \%$ and $28 \%$ in Finland, 3\% and 10\% in Germany, and 1\% and 9\% in Sweden. Otherwise, the ratio of inland catch to marine catch in terms of weigh was less than $1 \%$ in 13 countries, between $1-5 \%$ in 10 countries, between $5-10 \%$ in two countries and more than $10 \%$ in eight countries, some of which were landlocked.

On the basis of information compiled in this study, the magnitude of direct employment in the commercial fisherman's profession in inland waters usually ranges in hundreds in EIFAC member countries. In some countries the number of commercial inland fishers still has a declining trend (e.g. Poland, Netherlands), whereas in some others the figures have more 
Table II

Property rights regimes of inland waters/fisheries in EIFAC member countries.

Tableau II

Régimes de droits de propriété des eaux intérieures vis-à-vis de la pêche dans les pays membres de la CECPI.

\begin{tabular}{|c|c|c|c|c|}
\hline Country & Lakes & Rivers & Reservoirs & Estuaries/lagoons \\
\hline Albania & $100 \%$ state-owned & $100 \%$ state-owned & $100 \%$ state-owned & $100 \%$ state-owned \\
\hline Austria & $\begin{array}{l}\text { mostly private } \\
\text { (fishing rights) }\end{array}$ & $\begin{array}{l}\text { mostly private (fishing } \\
\text { rights) }\end{array}$ & $\begin{array}{l}\text { mostly private (fish- } \\
\text { ing rights) }\end{array}$ & inland country \\
\hline Belgium & no natural lakes & $\begin{array}{l}\text { navigable/floatable } \\
\text { are state-owned }\end{array}$ & & \\
\hline Bos. \& Her. & $\begin{array}{l}\text { state/public } \\
\text { ownership }\end{array}$ & $\begin{array}{l}\text { state/public } \\
\text { ownership }\end{array}$ & $\begin{array}{l}\text { state/public } \\
\text { ownership }\end{array}$ & \\
\hline Bulgaria & $\begin{array}{l}\text { most small and mid } \\
\text { size are private }\end{array}$ & $\begin{array}{l}100 \% \text { public } \\
\text { state ownership }\end{array}$ & $\begin{array}{l}4105 \text { municipal, } 947 \\
\text { state, } 55 \text { private }\end{array}$ & \\
\hline Croatia & $\begin{array}{l}\text { most are } \\
\text { state-owned }\end{array}$ & $19 \%$ state, $81 \%$ local & & \\
\hline Cyprus & $100 \%$ state-owned & $100 \%$ state-owned & $100 \%$ state-owned & $100 \%$ state-owned \\
\hline Czech Rep. & & $100 \%$ public property & & inland country \\
\hline Denmark & $\begin{array}{l}25 \% \text { state-owned, } \\
75 \% \text { private }\end{array}$ & $100 \%$ private & included in lakes & \\
\hline Estonia & $100 \%$ state-owned & $100 \%$ state-owned & $100 \%$ state-owned & $100 \%$ state-owned \\
\hline Finland & $\begin{array}{l}\text { mainly private (10 } \\
\text { largest with public) }\end{array}$ & mainly private & mainly private & \\
\hline France & mostly private & $\begin{array}{l}96 \% \text { private, } 4 \% \\
\text { public }\end{array}$ & & \\
\hline Germany & mostly state/public & mostly state/public & mostly state/public & mostly state/public \\
\hline Greece & state property & state property & state property & state property \\
\hline Hungary & mostly state-owned & mostly state-owned & mostly state-owned & inland country \\
\hline Iceland & $\begin{array}{l}\text { associated with } \\
\text { landowner (private) }\end{array}$ & $\begin{array}{l}\text { associated with } \\
\text { landowner (private) }\end{array}$ & & \\
\hline Ireland & generally private & generally private & generally private & $\begin{array}{l}\text { generally public } \\
\text { (tidal waters) }\end{array}$ \\
\hline Israel & public property & public property & public property & public property \\
\hline Italy & $\begin{array}{l}\text { state-owned public } \\
\text { property }\end{array}$ & $\begin{array}{l}\text { state-owned public } \\
\text { property }\end{array}$ & $\begin{array}{l}\text { state-owned public } \\
\text { property }\end{array}$ & $\begin{array}{l}\text { state-owned public } \\
\text { property }\end{array}$ \\
\hline Latvia & mostly state-owned & $\begin{array}{l}\text { mostly private (fishing } \\
\text { rights) }\end{array}$ & partly privatized & \\
\hline Lithuania & mostly state-owned & mostly state-owned & mostly state-owned & $\begin{array}{l}\text { Curonian Lagoon } \\
\text { is state-owned }\end{array}$ \\
\hline Luxembourg & no natural lakes & $\begin{array}{l}\text { 7\% state-owned, 93\% } \\
\text { private }\end{array}$ & & inland country \\
\hline Netherlands & $\begin{array}{l}\text { typically associated } \\
\text { with landowner }\end{array}$ & $\begin{array}{l}\text { typically associated } \\
\text { with landowner }\end{array}$ & $\begin{array}{l}\text { typically associated } \\
\text { with landowner }\end{array}$ & $\begin{array}{l}\text { associated with } \\
\text { landowner }\end{array}$ \\
\hline Norway & mostly private & mostly private & mostly private & mostly private \\
\hline Poland & $>99 \%$ public waters & $100 \%$ public waters & $100 \%$ public waters & $100 \%$ public waters \\
\hline Portugal & no lakes & 99\% state-owned & 99\% state-owned & 99\% state-owned \\
\hline Romania & $\begin{array}{l}\text { state-owned } \\
\text { (fisheries) }\end{array}$ & $\begin{array}{l}\text { state-owned } \\
\text { (fisheries) }\end{array}$ & $\begin{array}{l}\text { state-owned } \\
\text { (fisheries) }\end{array}$ & $\begin{array}{l}\text { state-owned } \\
\text { (fisheries) }\end{array}$ \\
\hline Slovakia & $\begin{array}{l}\text { state-owned } \\
\text { (fishing rights) }\end{array}$ & $\begin{array}{l}\text { state-owned } \\
\text { (fishing rights) }\end{array}$ & $\begin{array}{l}\text { state-owned } \\
\text { (fishing rights) }\end{array}$ & $\begin{array}{l}\text { state-owned } \\
\text { (fishing rights) }\end{array}$ \\
\hline Spain & mostly public & public & public & mostly public \\
\hline Sweden & $\begin{array}{l}\text { mostly private } \\
\text { (5 largest with public) }\end{array}$ & private & private & private \\
\hline Switzerland & $\begin{array}{l}\text { cantons have } \\
\text { exclusive rights }\end{array}$ & $\begin{array}{l}\text { cantons have } \\
\text { exclusive rights }\end{array}$ & \begin{tabular}{|l} 
cantons have \\
exclusive rights
\end{tabular} & inland country \\
\hline Turkey & $\begin{array}{l}\text { state-owned } \\
\text { (fishing waters) }\end{array}$ & $\begin{array}{l}\text { state-owned } \\
\text { (fishing waters) }\end{array}$ & $\begin{array}{l}\text { state-owned } \\
\text { (fishing waters) }\end{array}$ & $\begin{array}{l}\text { state-owned } \\
\text { (fishing waters) }\end{array}$ \\
\hline UK & $100 \%$ private & $100 \%$ private & included in lakes & $99 \%$ state-owned \\
\hline
\end{tabular}




\section{Table III}

Commercial inland catch and employment for EIFAC member countries by property rights regime.

Tableau III

Captures commerciales et emploi pour les pays membres de la CECPI selon le régime de droit de propriété.

\begin{tabular}{|l|c|c|c|c|c|}
\hline Property rights regime & $\begin{array}{c}\text { Inland water } \\
\text { area }\left(\mathrm{km}^{2}\right)\end{array}$ & $\begin{array}{c}\text { Catch } \\
\text { (tonnes) }\end{array}$ & $\begin{array}{c}\text { Employment } \\
\text { (number } \\
\text { of fishers) }\end{array}$ & $\begin{array}{c}\text { Catch/inland } \\
\text { water area } \\
\left.\text { (tonnes } \cdot \mathrm{km}^{-2}\right)\end{array}$ & $\begin{array}{c}\text { Employment/ } \\
\text { inland water area } \\
\text { (number of fishers } \mathrm{km}^{-2} \text { ) }\end{array}$ \\
\hline $\begin{array}{l}\text { Countries with mostly } \\
\text { state/public ownership } \\
\text { of inland waters/fisheries }\end{array}$ & 67166 & 75320 & 24836 & 1.12 & 0.37 \\
\hline $\begin{array}{l}\text { Countries with mostly } \\
\text { private ownership } \\
\text { of inland waters/fisheries }\end{array}$ & 105618 & 12926 & 4350 & 0.12 & 0.04 \\
\hline
\end{tabular}

or less stabilized (e.g. Sweden, France) or are even slightly increasing (Finland). Contrary to the common declining trend, figures in Estonia indicate an increase in number (see Mitchell et al., 2010).

\section{> COMPARISON OF CATCH AND EMPLOYMENT BY PROPERTY RIGHTS REGIMES}

Inland water area is much greater for EIFAC member countries with mostly private ownership of inland waters, owing to the large amount of lake area in Finland, Sweden and Norway; $39 \%$ of inland waters and fisheries were mostly public and $61 \%$ private. However, commercial inland catch and employment (number of fishers) for EIFAC member countries with mostly public ownership were nearly six times greater than for those with mostly private ownership (Table III). As a result, the ratios of both commercial inland catch and employment to inland water area are over nine times greater for EIFAC member countries with mostly public ownership of inland waters/fisheries.

Figure 1 shows that individual EIFAC member countries with the largest values for socioeconomic indicators of commercial inland fishing (catch and employment), are also generally those with mostly state/public ownership of inland waters/fisheries. This same trend holds true when inland water area is taken into account (Figure 2). According to accessible information, Turkey has the most catch (44 000 tonnes) and employment (7670 fishers).

\section{DISCUSSION}

Legislation is one of the ways to set up appropriate institutional structures and legal frameworks in resource management. Property right regimes and fishing rights are key concepts as they formulate access to commercial inland fisheries. This study showed that commercial fishers are faced with great variability in terms of right to access and availability of inland waters for commercial harvesting with EIFAC member countries. Although both public ownership and privatization are themselves subject to failure in some instances (Ostrom et al., 1999), in the EIFAC member countries fisheries management based on public property rights resulted in larger catches and higher employment than on private, when confronted with more or less similar environments.

However, some factors can explain the result. First, economic efficiency is only one of the objectives society may set for the use of fishery resources (Gordon, 1953) and impacts at community level should also be taken into consideration. Bioeconomic analysis (e.g. Clark, 1990) 


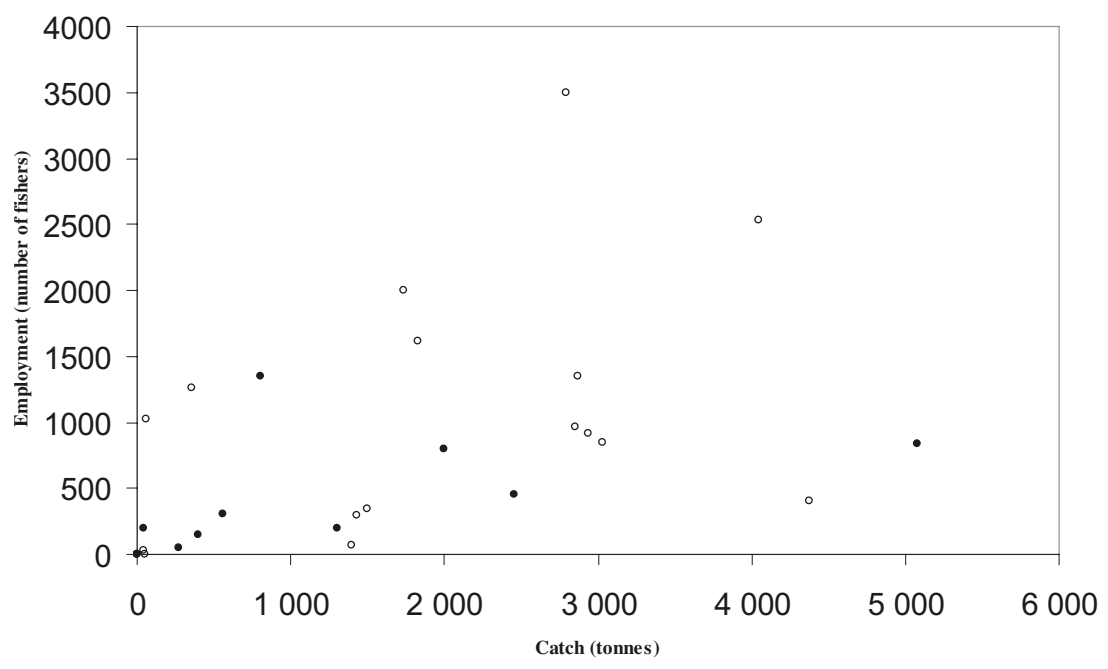

- Countries with mostly state/public ownership of inland waters/fisheries (not including Turkey)

- Countries with mostly private ownership of inland waters/fisheries

\section{Figure 1}

Socio-economic indicators of commercial inland fishing in EIFAC member countries.

Figure 1

Indicateurs socio-économiques de la pêche commerciale dans les eaux continentales des pays membres de la CECPI.

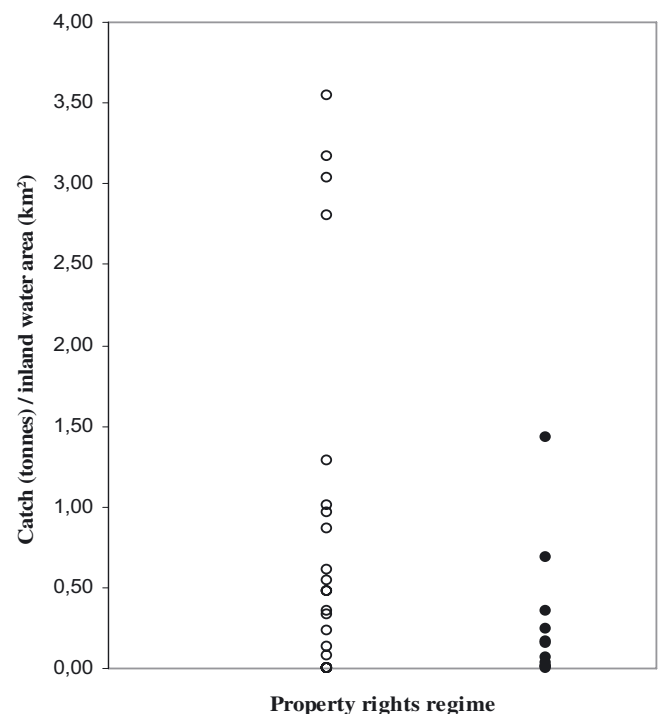

- Countries with mostly state/public ownership of inland waters/fisheries

- Countries with mostly private ownership of inland waters/fisheries

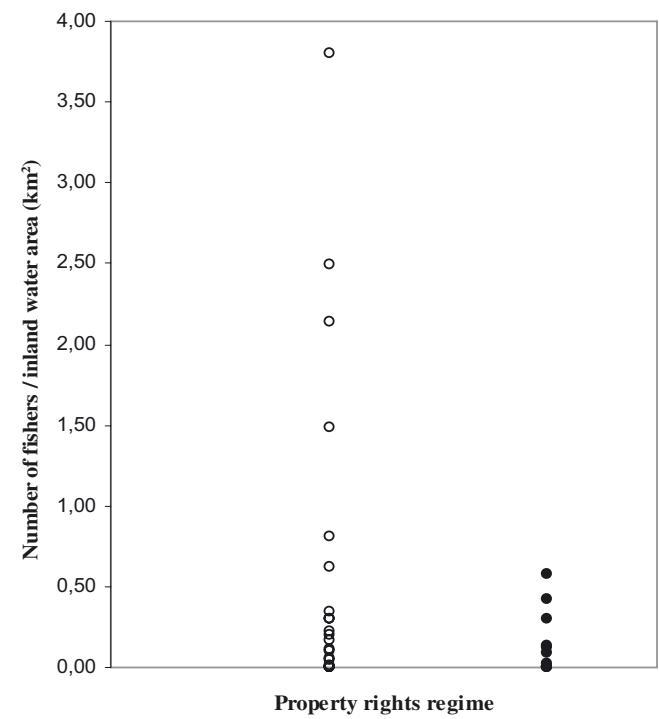

- Countries with mostly state/public ownership of inland waters/fisheries

- Countries with mostly private ownership of inland waters/fisheries

\section{Figure 2}

Comparison of socio-economic indicators of commercial inland fishing (based on inland water area) in EIFAC member countries by property rights regime.

Figure 2

Comparaison des indicateurs socio-économiques de la pêche commerciale (versus la surface des eaux intérieures) dans les eaux continentales des pays membres de la CECPI selon le régime de propriété. 
show how, even in the case of sole owner, it may be rational from a private financial perspective to drive a fish stock to extinction in the pursuit of profits (Radomski, 1999; Charles, 2001): private ownership does not guarantee sustainable exploitation (Hilborn et al., 1995). On the contrary in Finland and Sweden fisheries legislation confers numerous privileges on commercial fisheries and state ownership of certain water areas important for commercial fishers has facilitated their access to inland fishing grounds (Sipponen et al., 2006).

Second, management of fisheries is one of the basic actions needed in any fisheries system. The dicotomic scale of property rights regimes used in this analysis does not reveal the diversity of managerial bodies in practical fisheries management; there exist fisheries management systems which are based on co-management. Many factors may also blur the basic typology of fishing rights regimes. For example, in their European-wide study Pawson et al. (2008) appreciated that interpretations of fisheries legislation of different countries may not capture the intended meaning.

Clearly defined property rights are anticipated to lead into sustainable resource management, as they encourage players to adapt a conservation ethic and move towards fishery sustainability (Charles, 2001). Therefore management rights, i.e. the right to be involved in the design and implementation of management measures, are essential factor in the decisionmaking system of a fishery and are often linked with co-management approach as well as with ecosystem approach in fisheries (FAO, 2003). Hilborn (2008) noticed that restricted access, maintenance of biological productivity and co-operations of stakeholders are elements of well managed fisheries. Co-management, in turn, can be regarded as an application of the principle of subsidiarity to fisheries management (Noble, 2000).

The main implications of the resource regime to fishers as entrepreneurs are restrictions posed on fishermen. In order to operate successfully, a fishing enterprise or a fisherman should have access to sufficient waters (in order to find the fish) and to a sufficient number of gears (in order to catch the fish) that would enable long-term fishing activities (Sipponen et al., 1999). From the fisher's point of view, institutional arrangements play a significant role in management as they can ensure fishing enterprises a certain degree of stability in terms of operations and security of access - in particular, regarding capital-intensive sectors like trawling. For fishers, also diversification of fisheries is a way to increase flexibility and mitigate the risk of fluctuations in the abundance and availability of fish stocks (see Sipponen et al., 2006), i.e. adhering to portfolio-management (e.g. Hilborn et al., 2001). In fisheries management, realisation of the predicted shift of the paradigm from utilisation to conservation (Cowx and Arlinghaus, 2008) may profoundly affect commercial inland fisheries.

In 2005 the EU-27 catches from inland waters only accounted for a little over $1 \%$ of the world catch from such waters and only $2 \%$ of the catches from all EU-27 fisheries. However, the contribution of the 12 new Member States to the EU-27 total from inland fisheries (36\%) was relatively high compared with their contribution to the catches from marine areas (10\%) (European Commission, 2007). At least in certain countries these figures include also recreational catch. According to Eurostat (European Commission, 2007), catches from inland waters of the 27 EU-member countries were 124717 tonnes in 2005; the data we compiled for this study established approximately 90000 tonnes total commercial inland catch from the 33 EIFAC member countries.

There have been an estimated 18000 commercial inland fishermen in Central and Eastern European countries (Aps et al., 2004). According to the data we compiled for this study, the total number of professional inland fishers in the 33 EIFAC member countries is approximately 30 000. However, in the period since 1990 there has been a general reduction in the number of fishermen in most of the countries cited.

\section{CONCLUSIONS}

Public property right regimes accounted for higher catches and employment than the private one in the EIFAC member countries, which contradicts the presumption of privatisation of fishing rights as a tool to increase efficiency of commercial utilisation of inland waters 
fish resources. Individual countries show a clear picture of ownership regime as one of the essential factors affecting the prerequisites for carrying out commercial inland fishing. Presently the occupation has had to adapt itself to the legislative framework, which can be used to facilitate interaction between players, among them commercial fishers. Also, the dimensions of entrepreneurship of commercial inland fishers deserve more attention in order to reach balanced outcomes from allocation of fish resources and other managerial decisions.

There is a need for social innovations as far as fisheries management systems are concerned. The challenge is not only to build participatory institutions at various levels, but also to develop spatial and hierarchical links that guarantee resource conservation and equitable distribution of resources. The basic idea is to develop the institutional set up so that it will allow and foster user participation.

Even though in many countries the contribution of fisheries to GNP is often less than $1 \%$, and consequently that of commercial inland fisheries or regional figures are even less, the picture is one-sided: the reality on fishing grounds is more versatile. Because inland fisheries are not a miniature of marine fisheries, ecological, economical and social dimensions and their local specificities need to be considered. In spite of the relative small figures of commercial fishers, the branch is anticipated to have development potential in the provision of new kind of services related with tourism and management of aquatic ecosystem, thereby linking fisheries and environmental policies.

Due to the diversity and complexity of fisheries management, fisheries legislation should support co-governance arrangements, which enable regional, local and fishing strategy specific communication and collaboration between stakeholders.

\section{REFERENCES}

Aps R., Sharp R. and Kutonova T., 2004. Freshwater Fisheries in Central \& Eastern Europe: the Challenge of Sustainability. Overview Report, IUCN/SSC Fisheries Working Group, IUCN, Warsaw.

Berkes F. and Farvar M.T., 1989. Introduction and overview. In: Berkes F. (ed.), Common Property Resources. Ecology and community-based sustainable development, Belhaven press, A division of Pinter Publishers, London, 1-17.

Berkes F., Feeny D., McCay B.J. and Acheson J.M., 1989. The benefits of the commons. Nature, 340, 91-93.

Bromley D.W., 1991. Environment and Economy. Property rights and Public Policy, Blackwell.

Charles A.T., 2001. Sustainable Fishery Systems. Fish and Aquatic Resources Series, 5, Blackwell Science Ltd.

Ciriacy-Wantrup S.V. and Bishop R.C., 1975. "Common property" as a concept in natural resources policy. Nat. Resour. J., 15, 713-727.

Clark C.W., 1990. Mathematical Bioeconomics. The Optimal Management of Renewable Resources, Second edition, John Wiley \& Sons, Inc., New York.

Cowx I. and Arlinghaus R., 2008. Recreational fisheries in the twenty-first century. Towards a code of conduct. In: Aas $\varnothing$. (ed.), Global challenges in recreational fishing, Blackwell Publishing Ltd., 338353.

Dill W.A., 1990. Inland fisheries of Europe. EIFAC Technical Paper, n 52, FAO, Rome.

Dill W.A., 1993. Inland fisheries of Europe. EIFAC Technical Paper, n 52, Suppl. FAO, Rome.

European Commission, 2007. Fishery statistics. Data 1990-2006. Eurostat. Luxembourg: Office for Official Publications of the European Communities.

European Commission, 2008. European Fisheries Fund 2007-2013 - A user's guide. Luxembourg: Office for Official Publications of the European Communities.

FAO, 1992. Inland Water Resources and Aquaculture Service, Fishery Resources and Environment Division. 1992. Review of the state of world fishery resources. Part 2: Inland fisheries and aquaculture. FAO Fisheries Circular (FAO), $\mathrm{n}^{\circ} 710$ (rev.8), Rome, FAO.

FAO, 1995. Review of Inland Fisheries and Aquaculture in the EIFAC Area by Subregion and Subsector. FAO Fisheries Report $n^{\circ}$ 509, Suppl. 1, Rome. 
FAO, 1997. Fisheries Department, Inland fisheries. FAO Technical Guidelines for Responsible Fisheries, $\mathrm{n}^{\circ}$ 6, Rome.

FAO, 1999. Inland Water Resources and Aquaculture Service, Fishery Resource Division. Review of the state of world fishery resources: inland fisheries. FAO Fisheries Circular, $n^{\circ}$ 942, Rome.

FAO, 2003. FAO Technical Guidelines for Responsible Fisheries, $n^{\circ}$ 4, Suppl. 2, Rome.

Gordon H.S., 1953. An economic approach to the optimum utilization of fishery resources. J. Fish. Res. Bd. Can., 10, 442-457.

Hilborn R., 2008. Knowledge on How To Achieve Sustainable Fisheries. In: Tsukamoto K., Kawamura T., Takeuchi T., Beard T.D. Jr. and Kaiser M.J. (eds.), Fisheries for Global Welfare and Environment, 5th World Fisheries Congress, TERRAPUB, 45-56.

Hilborn R., Walters C.J. and Ludwig D., 1995. Sustainable Exploitation of Renewable Resources. Annu. Rev. Ecol. Syst., 26, 45-67.

Hilborn R., Maguire J.J., Parma A.M. and Rosenberg A.A., 2001. The precautionary approach and risk management: can they increase the probability of successes in fishery management. Can. J. Fish. Aquat. Sci., 58, 99-107.

Leria C., 2001. Legislation. In: Welcomme R.L. (ed.), Inland fisheries. Ecology and Management, FAO, Fishing News Books, 313-325.

Mitchell M., Vanberg J. and Sipponen M., 2010. Commercial inland fishing in member countries of the European Inland Fisheries Advisory Commission (EIFAC): Operational environments, property rights regimes and socio-economic indicators, EIFAC Ad Hoc Working Party on Socio-Economic Aspects of Inland Fisheries, Mimeograph.

Noble B.F., 2000. Institutional criteria for co-management. Mar. Policy, 24, 69-77.

North D.C., 1990. Institutions, institutional change and economic performance, Cambridge University Press, Cambridge.

OECD, 1997. Towards Sustainable Fisheries. Economic Aspects of the Management of Living Marine Resources, OECD, Paris, 9-177.

O'Kelly E., 1976. Survey of ownership and utilization of inland fisheries in various European countries and Canada. EIFAC Occasional Paper, n ${ }^{\circ}$ 11, FAO, Rome.

Ostrom E., 2000. Private and common property rights. Workshop in Political Theory and Policy Analysis, and Center for the Study of Institutions, Population, and the Environmental Change, Indiana University, 332-379.

Ostrom E., Burger J., Field C.B., Norgaard R.B. and Policansky D., 1999. Revisiting the Commons: Local Lessons, Global Challenges. Science, 284, 278-282.

Pawson M.G., Glenn N. and Padda G., 2008. The definition of marine recreational fishing in Europe. Mar. Policy, 32, 339-350.

Radomski P.J., 1999. Commercial Overfishing and Property Rights. Fisheries, 24, $22-29$.

Salz P., Buisman E., Smit J. and de Vos B., 2006. Employment in the fisheries sector: current situation (FISH/2004/4). Final report EU, April 2006.

Sipponen M., Muje K., Marjomäki T.J., Valkeajärvi P. and Karjalainen J., 2006. Interlocked use of inland fish resources: a new management strategy inder private property rights. Fish. Manage. Ecol., 13, 299-307.

Sipponen M., Niittykangas H. and Salo H., 1999. The adaption of professional fishing to diminished vendace stocks. The case of Finnish inland waters. N. Am. J. Fish. Manage., 19, 737-747.

Symes D., 1998a. Towards a Property Rights Framework for the Management of Europe's Fisheries. In: Symes D. (ed.), Property Rights and Regulatory Systems in Fisheries, Fishing News Books, Blackwell Science Ltd, Oxford, 257-264.

Symes D., 1998b. Property Rights, Regulatory Measures and the Strategic Response of Fishermen. In: Symes D. (ed.), Property Rights and Regulatory Systems in Fisheries, Fishing News Books, Blackwell Science Ltd., Oxford, 3-16. 